\title{
Retracted: A Showcase of Bench-to-Bedside Regenerative Medicine at the 2010 ASNTR
}

\section{The Scientific World Journal}

Received 27 June 2012; Accepted 27 June 2012

Copyright (C) 2012 The Scientific World Journal. This is an open access article distributed under the Creative Commons Attribution License, which permits unrestricted use, distribution, and reproduction in any medium, provided the original work is properly cited.

The article titled "A Showcase of Bench-to-Bedside Regenerative Medicine at the 2010 ASNTR" [1], published in TheScientificWorldJOURNAL, has been retracted as it was found to have violated the journal's policy against citation manipulation.

\section{References}

[1] D. J. Eve, C. V. Borlongan, and P. R. Sanberg, "A showcase of bench-to-bedside regenerative medicine at the 2010 ASNTR," TheScientificWorldJOURNAL, vol. 11, pp. 1842-1864, 2011. 